\title{
ANALISIS KEPUASAN KONSUMEN TERHADAP PRODUK IKAN PINDANG DI PASAR PRAJEKAN
}

\author{
Kholifatun Jannah' ${ }^{1)}$, Sutrisno ${ }^{2 *}$ \\ Fakultas Pertanian, Universitas Abdurachman Saleh Situbondo \\ *Email Korespondensi : sutrisno78@gmail.com
}

\begin{abstract}
Abstrak
Karakteristik dari pengolahan tradisional adalah kemampuan pengetahuan pengolah rendah dengan keterampilan yang diperoleh secara turun-menurun, tingkat sanitasi dan hygiene rendah, sesuai dengan keadaan disekitarnya. Ikan pindang merupakan salah satu hasil olahan yang cukup populer di Indonesia, dalam urutan hasil olahan tradisional menduduki tempat kedua setelah ikan asin. Permintaan ikan pindang di Bondowoso tepatnya di Kecamatan mereka yang datang lalu bertransaksi ikan pindang di pasar Prajekan merupakan pedagang kebanyakan tengkulak. Pasar Prajekan merupakan salah satu pasar di Kota Bondowoso yang menjual ikan pindang yang berkualitas. Pada saat membeli ikan, masyarakat mempertimbangkan beberapa faktor seperti harga, pelayanan dan kondisi kesegaran ikan. Jenis ikan laut yang pada umumnya dikonsumsi oleh masyarakat prajekan adalah ikan tongkol, cakalan, layang, teri dan udang.
\end{abstract}

Kata Kunci : Sanitasi, hygiene, permintaan ikan pindang, Kabupaten Bondowoso

\begin{abstract}
The characteristics of traditional processing are the ability of low processing knowledge with skills acquired in stages, low levels of sanitation and hygiene, according to the surrounding conditions. Pindang fish is one of the processed products that is quite popular in Indonesia, in the order of traditional processed products occupying second place after salted fish. The demand for prawns in Bondowoso, precisely in their sub-district, which comes and transacts pindang fish in the Prajekan market, is a trader of mostly middlemen. Prajekan Market is one of the markets in Bondowoso City that sells quality pindang fish. When buying fish, the community considers several factors such as price, service and freshness of the fish. The types of marine fish that are generally consumed by pre-harvested people are tuna, cakal, kite, anchovies and shrimp.
\end{abstract}

Keyword: Sanitation, hygiene, demand for pindang fish, Bondowoso Regency

\section{PENDAHULUAN}

Subsektor perikanan mempunyaiperanan penting sebagai penyumbang proteinbagi masyarakat Indonesia.Ikan selainmerupakan sumber protein, juga diakuisebagai "functional food" yang mempunyaiarti penting bagi kesehatan karenamengandung asam lemak tidak jenuh berantaipanjang (terutama yang tergolong asam lemakomega-3), vitamin, serta makro dan mikromineral. Akan tetapi tidak semua wilayahIndonesia dapat tercukupi kebutuhannya akanprotein karena ketersediaan ikan perkapitabelum terdistribusi secara merata. Pengolahandapat membuat ikan menjadi awet danmemungkinkan untuk didistribusikan daripusat produksi ke pusat konsumsi.Namun,selama 20 tahun terakhir produksi ikan yangdiolah baru sekitar 23-47\%, dan dari jumlahtersebut sebagian besar merupakan jenispengolahan tradisional.Ditinjau dari hasilolahan ikan, sebesar 75\% ikan masih diolahsecara tradisional.Pengolahan dilakukandengan skala usaha rumah tangga kecil yangsecara kualitas maupun kuantitasnya masihsangat minim, sehingga mempunyai nilai jualyang 
rendah (Martasuganda, S, dkk, 2003). Karakteristik dari pengolahan tradisional adalah kemampuan pengetahuan pengolah rendah dengan keterampilan yang diperoleh secara turun-menurun, tingkat sanitasi danhygiene rendah, sesuai dengan keadaan disekitarnya yang umumnya tidak memiliki sarana air bersih, permodalannya sangat lemah, peralatan yang digunakan sangatsederhana dan pemasaran produk hanyaterbatas pada pasaran lokal (Direktorat Jenderal Perikanan Tangkap, 2015). Pengolahan modern memerlukanpersyaratan yang sulit dipenuhi olehperikanan skala kecil, yaitu pasokanbahan baku yang bermutu tinggi dalamjenis dan ukuran yang seragam, dalamjumlah yang cukup banyak sesuaidengan kapasitas industri. Kondisi di atas menggambarkan bahwa pengolahan ikan tradisional masih mempunyai prospek untuk dikembangkan. Prospek ini didukungoleh masih tersedianya sumber dayaikan di pusat produksi, tingginyapermintaan di pusat konsumsi, sederhananya teknologi, serta banyaknya industri rumah tangga pengolah tradisional. Menurut terminologi FAO (Heruwati, E,S. 2015) ikan olahan tradisional, atau "traditional curred " adalah produk yangdiolah secara sederhana dan umumnya dilakukan pada skala industri rumah tangga. Jenis olahan yang termasuk produk olahan tradisional ini adalah ikan kering atau ikan asin kering, ikan pindang, ikan asap, serta produk fermentasi yaitu kecap, peda, terasi, dan sejenisnya.

Ikan pindang merupakan salah satu hasil olahan yang cukup populer di Indonesia, dalam urutan hasil olahan tradisional menduduki tempat kedua setelah ikan asin. Dilihat dari sudut program peningkatan konsumsi protein masyarakat, ikan pindang mempunyai prospek yang lebih baik daripada ikan asin. Ikan pindang sendiri merupakan produk yang banyak ditemui di area pasar Situbondo, karena ikan pindang dapat diproduksi sendiri oleh masyarakat Situbondo, sehingga dalam memasarkan produk ikan pindang ini tak hanya disalurkan di Situbondo saja melainkan di kawasan luar Kabupaten Situbondo, seperti daerah Prajekan.

Pasar Prajekan merupakan salah satu pasar di Kota Bondowoso yang menjual ikan pindang yang berkualitas.Pada saat membeli ikan, masyarakat mempertimbangkan beberapa faktor seperti harga, pelayanan dan kondisi kesegaran ikan. Jenis ikan laut yang pada umumnya dikonsumsi oleh masyarakat prajekan adalah ikan tongkol, cakalan, layang, teri dan udang.

Kepuasan adalah tingkat perasaan seseorang setelah membandingkan kinerja/hasil yang dirasakannya dengan harapannya. Apabila kinerja dibawah harapan, maka pelanggan akan kecewa. Bila kinerja sesuai harapan, maka pelanggan akan puas (Suprapto, 2006). Masyarakat yang terkesan puas terhadap produk ikan yang terhadap ikan karena merasa cocok terhadap harga, tempat, rasa dan kesegaran ikan tersebut.

Berdasarkan penjelasan yang telah dipaparkan diatas, maka dapat diidentifikasikan rumusan masalah sebagai berikut : 1. Bagaimana respon konsumen terhadap ikan pindang di pasar prajekan?. 2. Bagaimana kepuasan konsumen terhadap ikan pindang di pasar prajekan?. 3. Bagaimana kriteria yang paling dominan terhadap keputusan pembelian konsumen pada ikan pindang di pasar prajekan?

\section{METODE PENELITIAN}

Metode yang digunakan dalam penelitian ini adalah metode survey (kuisioner). Data yang digunakan dalam penelitian ini adalah data primer dan data sekunder.Data primer yang diperoleh dengan menggunakan teknik memberikan pertanyaan langsung kepada responden.

Dalam hal ini responden (konsumen) ikan pindang, dengan menggunakan daftar pertanyaan (kuisioner) sebagai alat bantu pengumpulan data, Sedangkan data sekunder diperoleh dari seluruh pemilik usaha ikan pindang yang terkait dalam penelitian ini, yaitu para pedagang di pasar Prajekan. 


\section{HASIL DAN PEMBAHASAN}

\section{Skala Likert}

Respon konsumen pada ikan pindang di pasar Prajekan Kabupaten Bondowoso dapat dibedakan menjadi 5 kategori yaitu respon sangat puas, puas, kurang puas, tidak puas dan sangat tidak puas. kepuasan dikatakan sangat tidak puas jika jawaban dari konsumen sampel mempunyai skor pada interval 0 - 19,99 dikatakan tidak puas apabila skor jawaban konsumen interval 0,20 - 39,99 dikatakan cukup puas apabila jawaban konsumen memiliki skor pada interval 0,40 - 59,99 dikatakan puas apabila jawaban konsumen pada interval 0,60 - 79,99 dan kepuasan dikatakan sangat puas apabila berada pada interval $0,80-100$.

Tabel 1. Tingkat respon konsumen terhadap kepuasan konsumen pada kualitas produksi Ikan Pindang di pasar Prajekan Kabupaten Bondowoso

\begin{tabular}{|c|c|c|c|c|}
\hline No & Uraian & Jumlah x Bobot & Persentase & Interprentasi \\
\hline $\mathrm{I}$ & Kualitas & & & \\
\hline 1 & 1.1 & 302 & $84 \%$ & Sangat Puas \\
\hline 2 & 1.2 & 309 & $86 \%$ & Sangat Puas \\
\hline 3 & 1.3 & 304 & $84 \%$ & Sangat Puas \\
\hline 4 & 1.4 & 291 & $81 \%$ & Sangat Puas \\
\hline
\end{tabular}

Sumber : Data hasil penelitian 2018

Item I ( Kualitas ) dapat diketahui bahwa sebesar 84 persen konsumen "sangat puas" mengenai kepuasan ikan pindang di pasar Prajekan, dapat diketahui bahwa sebesar 86 persen konsumen "sangat puas" mengenai respon konsumen terhadap ikan pindang di pasar Prajekan, diketahui bahwa sebesar 84 persen konsumen "sangat puas" mengenai rasa ikan pindang di pasar Prajekan dan diketahui bahwa sebesar 81 persen konsumen "sangat puas" mengenai tekstur ikan pindang di pasar Prajekan.

Tabel 2. Tingkat respon konsumen terhadap kepuasan konsumen pada harga produksi Ikan Pindang di pasar Prajekan Kabupaten Bondowoso

\begin{tabular}{|c|c|c|c|c|}
\hline No & Uraian & Jumlah x Bobot & Persentase & Interprentasi \\
\hline II & Harga & & & \\
\hline 1 & 2.1 & 302 & $84 \%$ & Sangat Puas \\
\hline 2 & 2.2 & 295 & $82 \%$ & Sangat Puas \\
\hline 3 & 2.3 & 301 & $84 \%$ & Sangat Puas \\
\hline 4 & 2.4 & 280 & $78 \%$ & Puas \\
\hline
\end{tabular}

Sumber : Data hasil penelitian 2018

Item II ( Harga ) dapat diketahui bahwa sebesar 84 persen konsumen "sangat puas" mengenai kepuasan konsumen ikan pindang di pasar Prajekan, dapat diketahui bahwa sebesar 82 persen konsumen "sangat puas" mengenai respon konsumen ikan pindang di pasar Prajekan, dapat diketahui bahwa sebesar 84 persen "sangat puas" mengenai harga sesuai dengan kualitas, dapat diketahui bahwa sebesar 78 persen konsumen "puas" mengenai tergolong murah ikan pindang di pasar Prajekan 
Tabel 3. Tingkat respon konsumen terhadap kepuasan konsumen pada tempat produksi ikan pindang di pasar Prajekan Kabupaten Bondowoso

\begin{tabular}{ccccc}
\hline No & Uraian & Jumlah x Bobot & Persentase & Interprentasi \\
\hline III & Tempat & & & \\
\hline 1 & 3.1 & 291 & $81 \%$ & Sangat Puas \\
\hline 2 & 3.2 & 300 & $83 \%$ & Sangat Puas \\
\hline 3 & 3.3 & 271 & $75 \%$ & Puas \\
\hline 4 & 3.4 & 292 & $81 \%$ & Sangat Puas \\
\hline Sumber : Data hasil penelitian 2018 & & &
\end{tabular}

Item III ( Tempat ) dapat diketahui bahwa sebesar 81 persen konsumen "sangat puas" mengenai Kepuasan konsumen ikan pindang di pasar Prajekan, dapat diketahui bahwa sebesar 83 persen konsumen "sangat puas" mengenai respon konsumen Ikan Pindang di pasar Prajekan, dapat diketahui sebesar 75 persen konsumen "puas" mengenai jarak rumah ke lokasi konsumen ikan pindang di pasar Prajekan, dan dapat diketahui sebesar 81 persen konsumen "sangat puas" mengenai lokasi sebagai letak strategis sebagai akses oleh konsumen ikan pindang di pasar Prajekan.

Tabel 4. Tingkat respon konsumen terhadap kepuasan konsumen pada pelayanan produksi ikan pindang di pasar Prajekan Kabupaten Bondowoso

\begin{tabular}{cccccc}
\hline No & Uraian & Jumlah x Bobot & Persentase & Interprentasi \\
\cline { 1 - 2 } IV & Pelayanan & & & \\
\hline 1 & 4.1 & 291 & $81 \%$ & Sangat Puas \\
\hline 2 & 4.2 & 283 & $79 \%$ & Puas \\
\hline 3 & 4.3 & 276 & $76 \%$ & Puas \\
\hline 4 & 4.4 & 226 & $63 \%$ & Puas \\
\hline
\end{tabular}

Sumber : Data hasil penelitian 2018

Item IV ( Pelayanan) dapat diketahui bahwa sebesar 81 persen konsumen "sangat puas" mengenai kepuasan konsumen ikan pindang di pasar Prajekan, dapat diketahui bahwa sebesar 79 persen konsumen "puas" mengenai respon konsumen ikan pindang di pasar Prajekan, dapat diketahui bahwa sebesar 75 konsumen "puas" mengenai produk yang ada di pasar Prajekan dapat terpenuhi kebutuhan konsumen ikan pindang di pasar Prajekan dan dapat diketahui bahwa sebesar 63 konsumen "puas" mengenai potongan harga terhadap konsumen ikan pindang di pasar Prajekan.

Jadi untuk rata-rata konsumen terhadap kepuasan konsumen pada ikan pindang di Pasar Prajekan Kabupaten Bondowoso sebesar 71\% berada pada nilai Interpretasi "puas"

Dan untuk hipotesa menjawab hipotesa ke tiga konsumen sebagi responden terhadap kepuasan konsumen ikan pindang dipasar Prajekan Kabupaten Bondowoso lebih dominan pada kualitas produk/rasa sebesar $84 \%$ berada pada nilai Interpretasi "sangat puas"

\section{Uji Z}

Untuk mengetahui besarnya respon konsumen terhadap kepuasan konsumenterhadap produksi ikan pindang dipasar Prajekan Kabupaten Bondowoso menggunakan Uji Proporsi, statistik pengujiannya : 


\section{Z Tabel :0,3461}

$$
\begin{aligned}
\text { Zhit } & =\frac{\mathrm{x} / \mathrm{n}-\mathrm{Po}}{\sqrt{\frac{\mathrm{Po}(1-\mathrm{Po})}{\mathrm{n}}}} \\
\text { Zhit }= & \frac{49 / 72-0,5}{\sqrt{\frac{0,5(1-0,5)}{72}}} \\
& =\frac{0,68}{0,06} \\
& =11,33
\end{aligned}
$$

Dari perhitungan diperoleh hasil Z hitung sebesar 11,33 > Z Tabel $(0,3461)$, sehingga Ha diterima dan Ho ditolak artinya responsedang terhadap kepuasan konsumen ikan pindang dipasar Praajekan Kabupaten Situbondo lebih dari 50 persen dari hasil keseluruhan pada lampiran 6 yang hasilnya terdapat 49 dari responden yang jumlahnya 72, dan hasil dari 49(Kurang puas) terdapat 46 yang berada pada kategori respon sedang $(0,40$ - 59,99)konsumen ikan pindang yang ada dipasar Prajekan Kabupaten Bondowoso, sedangnya respon kepuasan konsumen terhadap ikan pindang disebabkan oleh beberapa hal seperti :

a. Sedangnya yang memahami manfaat ikan pindang.

b. Sedangnya pengetahuan konsumen terhadap keawetan ikan pindang.

c. Sedangnya pemahaman inovasi baru yang menggunakan ikan pindang contoh ikan abon dan ikan sambel merah.

\section{KESIMPULAN}

Berdasarkan hasil analisis dan pembahasan yang telah dilakukan, maka dapat diambil beberapa kesimpulan :

1. Respon konsumen terhadap ikan pindang dipasar Prajekan Kabupaten Bondowoso tergolong sedang.

2. Kepuasan konsumen terhadap ikan pindang dipasar Prajekan Kabupaten Bondowoso tergolong tinggi atau dikatakan tinggi.

3. Kriteri yang paling dominan terhadap ikan pindang yaitu kualitas produk atau rasa.

\section{REFERENSI}

Adawyah, R. 2007. Pengolahan dan pengawetan ikan.Jakarta : Penerbit PT Bumi Aksara.

Aditiawarman, B.P 2000.Pengukuran tingkat kepuasan dan identifikasi ketidakpuasan pelayanan (Studi Kasus : Saving and Lending Unit Sucofindo). Skripsi Departemen Matematika dan Ilmu Pengetahuan Alam. Institut Pertanian bogor.

Astawan. 2004. Pemindangan secara tradisonal

Direktorat Jenderal Perikanan Tangkap. 2001. Inventarisasi Jenis dan Jumlah Produk Olahan Hasil Perikanan Skala Kecil di Indonesia. Departemen Kelautan dan Perikanan, Jakarta

Endang Sri Heruwati. 2002. Pengolahan ikan secara tradisional: Prospek dan peluang pengembangan. Pusat Riset pengolahan produk dan sosial ekonomi kelautan dan perikanan , Jl, K.S. Tahun petamburan VI, Jakarta. 
Heruwati, E,S. 2015. Pengolahan Ikan Secara Tradisional.

Nazir M. 1998. Metode Penelitian Jakarta: Ghalia Indonesia PS. 2008. Agribisnis Perikanan. Jakarta Penerbit Penebar Swadaya.

Martasuganda, S, dkk.2003.Teknologi Untuk PemberdayaanMasyarakat Pesisir. Dirjen Pemberdayaan MasyarakatPesisir. Departemen Kelautan dan Perikanan, Jakarta.

Suprapto, J. 2006. Pengukuran Tingkat Kepuasan Pelanggan Untuk Menaikkan Pangsa Pasar.PT. Rineka Cipta. Jakarta. 